\title{
COMMUNITY INVOLVEMENT IN LOCAL DEVELOPMENT: THEORETICAL ANALYSIS OF COMMUNITY DEVELOPMENT APPROACHES
}

\author{
Līga PAULA, Latvia University of Life Sciences and Technologies, Liela street 2, Jelgava, LV-3001, Latvia; Liga.Paula@1lu.lv
}

The aim of the study is to identify and describe community development approaches particularly emphasizing community-led local development as it dominates in the European Union as part of the rural development policy. The research is based on the literature review on community development approaches and community involvement in rural development. The most frequently used approaches are the following: community-led local development, community-led development, community driven development, community capacity building asset-based community development, and community economic development. The author concludes that the involvement of communities in development processes is promoted through specific programs implemented by policy makers and initiatives by communities and non-governmental organizations. Community involvement in development is influenced by many factors, such as democratic traditions and societal experience, the distribution of power and the exchange of knowledge between the social agents involved in development processes, the availability of resources and the skills to use them. Community projects are another way in which local agents can participate in improving the quality of life and solving local problems.

Keywords: community development, partnerships, rural development

\section{INTRODUCTION}

Community involvement in local development with varying degrees of success is taking place in all regions of the world including European countries. In this article, the author provides insights into the experiences of different countries, comparing theoretical approaches and describing the results of empirical research on community involvement in local development processes. The difficulty of defining community boundaries often complicates the understanding of community development as it is necessary to understand the level of development programs and initiatives that will be implemented (Bhattacharyya, 2004). Therefore, the aim of the study is to identify and describe community development approaches particularly emphasizing community-led local development as it dominates in the European Union (further in the text EU) as part of the rural development policy.

\section{METHODOLOGY}

The research is based on the semi-systematic literature review on community development approaches and community involvement in rural development. The semi-systematic or narrative review approach involving qualitative content analysis of the journal articles and other publications was used as a research method. This approach is useful to provide an overview of areas in which the research is disparate and interdisciplinary; its "aim is to provide an overview of a certain issue or research problem to evaluate the state of knowledge on a particular topic" (Snyder, 2019). Qualitative semi-systematic literature review is often used to detect themes and theoretical perspectives within a specific research discipline (Ward et al., 2009). By using qualitative content analysis (Titscher et al., 2000), community development approaches were identified and compared, emphasizing the core ideas and critical aspects. To grasp extensive community development experience and theoretical approaches, journal articles and other information sources focusing on different world regions and cultures were selected for the review. Later in the analysis, the author particularly focused on rural partnership approach as it is common for the EU countries.

\section{RESEARCH RESULTS}

During last few decades, community capacity building and community development strategies have become relevant in the world regions where new democracies have evolved including Central and Eastern Europe (Noya et al. (Eds.), 2009). Recently the neo-endogenous model or networked development (Lowe et at., 2019) gained greater academic interest as it anticipates specific needs of regions and local initiatives. Territorial communities, as capitalism-driven sites, have a combination of weaknesses and strengths that influence their development; as stated by DeFillippis and Saegert, community development initiatives take place in a context where the capital needed for 
survival and prosperity of the area is lacking: communities are unable to meet their needs and aspirations due to limited opportunities in capitalist political economy (DeFillippis, Saegert, 2012). The authors conclude that often people base their action against restrictions not on strategically based decisions, but on seeking to increase their capabilities in situations where only limited human, social and economic capital is available. Many people leave such areas, but others remain because they lack opportunities or are loyal to their local social networks and lifestyles (DeFillippis, Saegert, 2012). Also, Kumpulainen and Soini focus on rural communities as vital, viable and attractive places to live by analysing activities of village associations in Finland (Kumpulainen, Soini, 2019). At the same time, it must be acknowledged that not all people who leave communities completely break ties with them. In community development, a lot of effort is devoted to finding the best solutions and tools to gain resources beyond the geographical community (DeFillippis, Saegert, 2012) and to strengthen local economy (Cox, Mair, 1988).

In the policy documents, writing of community development practitioners and researchers in social sciences, community development approaches are called and defined in various ways. Table 1 provides a comparative overview of the community development approaches mentioned above. The most important of these are:

- community-led local development (European Commission, 2014; European Funding Network, 2012);

- community-led development or community driven development (Bowen, 2005; Mansuri, Rao, 2004);

- community capacity building (Eade, 2007; The Aspen Institute Rural Economic Policy Program);

- asset-based community development (MacLeod, Emejulu, 2014; Mathie, Cunningham, 2003; Kretzmann, McKnight, 1993);

- community economic development or local economic development (Krawchenko, 2014; Bently, Pugalis, 2014; Turvey, 2006; Cox, Mair, 1988).

Table 1. Community development approaches

\begin{tabular}{|c|c|}
\hline & Description of approaches \\
\hline 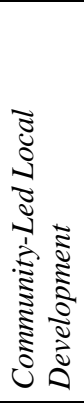 & $\begin{array}{l}\text { Main ideas: } \\
\text { according to a neo-endogenous approach, development is driven by local action groups whose members } \\
\text { represent local public and private socio-economic interests } \\
\text { the approach focuses on specific areas of the regions, as community initiatives are based on integrated and } \\
\text { multi-sectoral local development strategies, taking into account local needs and potential (bottom-up approach) } \\
\text { - strengthening innovation in the local context and capacity building, networking, cooperation, building } \\
\text { community ownership and community ownership, multi-level governance is essential } \\
\text { Criticism: } \\
\text { - concerns about the dominance of local authorities and power structures in decision-making } \\
\text { - a rather impractical approach in today's globalized world when balancing endogenous/ exogenous interests } \\
\text { and needs }\end{array}$ \\
\hline 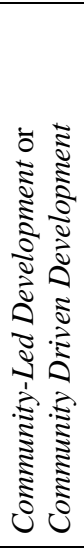 & $\begin{array}{l}\text { Main ideas: } \\
\text { people-centred approach to social change, where local agents play a leading role in conceptualizing } \\
\text { projects and programs geared to social and economic needs (special social fund projects for poverty alleviation, } \\
\text { sustainability, social services, social and economic infrastructure, more inclusive democracy, development of social } \\
\text { capital, strengthening of governance, measures to strengthen organizations) } \\
\text { - emphasizes the extensive cooperation between stakeholders to achieve greater resource efficiency, and } \\
\text { beneficiaries are actively involved in project design and management, including investment fund management } \\
\text { - Incorporation of local knowledge into decision-making processes through 'learning by doing' } \\
\text { Criticism: problems often lead to difficulties in defining the boundaries of communities, and thus in defining target } \\
\text { - } \\
\text { groups in this way, project-strengthened local institutions undermine democratically elected governments (their } \\
\text { - forces), and community initiatives are dominated by local elites } \\
\text { project promoters often ignore differences between target groups and highlight local authority structures, } \\
\text { thus focusing on more easily achievable and measurable outcomes, neglecting capacity building for collective action }\end{array}$ \\
\hline 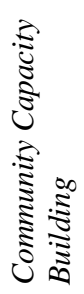 & $\begin{array}{l}\text { Main ideas: } \\
\text { approach involving the development of civil society, the development of community organizations, the } \\
\text { development of the knowledge and skills of community members } \\
\text { capacity consists of individual leadership, skills and resources, knowledge and tools as well as } \\
\text { organizations able to use it, control the conditions and factors affecting the quality of life in the community } \\
\text { Criticism: } \\
\text { - dependence on external resources may arise and there is a concern that community organizations will not } \\
\text { be able to adequately contribute to local capacity building }\end{array}$ \\
\hline
\end{tabular}




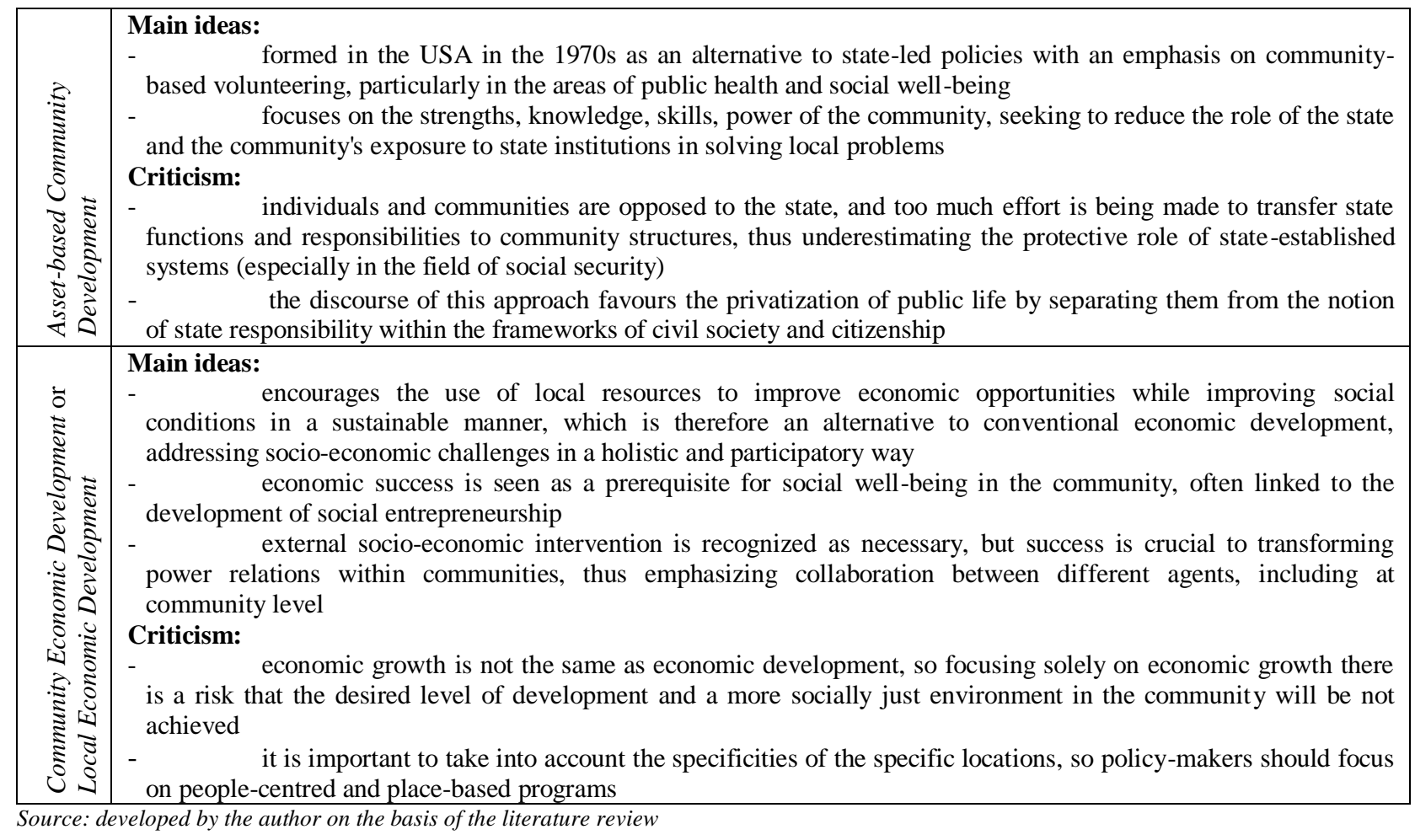

Approaches differ according to who initiates change (the community itself or external social agents), the degree of community involvement in planning, implementing, and monitoring initiatives, and the distribution of power and influence between local agents and public sector bodies that grant or provide funding for realization of initiatives. In the European Union, and thus also in Latvia, reference can be made to community involvement in development processes as defined by rural development policy as community-led local development (European Commission, 2014), which essentially means community-driven development.

Analysing the problems of rural community development in American sociology, Summers (Summers, 1986) pointed out that sociologists paid little attention to rural communities as an object of study in the mid-20th century. Such an attitude is based on the fact that external forces and processes (urbanization, industrialization, bureaucratisation and centralization) in rural communities have promoted vertical integration of communities, destroyed horizontal integration and changed the social organization of communities, making communities less influential by depriving them of local autonomy in decision making and absorbing them into our society. In his article, Sammers refutes much of these arguments by referring to various studies in the 1980s and arguing that vertical integration does not always weaken but even strengthen the horizontal, and that community influence is heavily dependent on local leaders, organizational structure of the decision-making within the community, and values of decision-makers (Summers, 1986). Similarly, referring to historical experience, Summers concludes that in times of social and economic crisis community development is more effective, as in these cases communities experience greater distrust in institutions external to communities (such as public authorities) from which support is not being received. Compared to urban areas, for the communities it is also important to develop networks of 'weak ties' (Granovetter, 1973) in the countryside with external social agents. Sammers emphasizes that there are different views in the context of rural community development. Some authors view community as a causal factor affecting the social, political, and economic well-being of local people, while others as a descriptive term for a stratification system, power structure, or human ecology that dominates in the particular locality (Summers, 1986, pp. 354). He also emphasizes discussion initiated by Kaufman (Kaufman, 1959) on development of community and development in community, where the last one is mostly related to economic development in the community (advanced economic relations, better services, etc.) (Summers, 1986). The idea of building (and strengthening) community capacity and appropriate support programs is usually extended to those who are at a disadvantage, have suffered more from the negative effects of globalization or economic crises, and have undergone severe economic restructuring and social change. Typically, they are developing countries, but in recent decades, community capacity building and community development strategies have emerged in other parts of the world where new democracies are developing, including Central and Eastern Europe (Noya et al., 2009). Since the 1980s, a number of programs have been implemented in the European Union, supporting local cooperation and development processes. The Poverty I (1975-1980), Poverty II (1980-1985) and Poverty III (1989-1994) poverty prevention programs should be mentioned first, while initiatives such as LEDA, LEADER, URBAN, INTERREG, NOW, Youthstart, HORIZON and INTEGRA developed local partnership frameworks and international rural partnership networks. The implementation of the LEADER program was the first attempt of the European Union to support local initiatives in rural areas by involving all key local agents in the implementation of multi-sectoral plans in their territories (O’Hara, 1998, pp. 28). The LEADER program has been implemented in several stages: LEADER I (1991- 
1994), LEADER II (1995-2001), LEADER + (2000-2006), LEADER as part of Axis 4 of the Rural Development Program (2007-2013) and LEADER as community-led local development defined within a framework of the Rural Development Program (2014-2020). In the countries of the EU, the program has gained great popularity and strengthened its position; while the first LEADER I program had 217 Local Action Groups (further in the text LAGs) in 12 EU Member States, it was already over 2030 in all EU Member States during the 2007-2013 programming period (Peters, 2012). The basic idea of the LEADER program was that community initiatives should develop innovative ideas that could be replicated ("copied") in other rural areas, thus contributing to rural development (Dargan \& Shucksmith, 2008). Evaluation of LEADER activities and scientific studies show that this idea has not always been realized, the presence of innovation in community initiatives should be analysed in a local context as innovation in particular areas. The role of LEADER is also linked to political capacity at regional level, for example by analysing participation in the program on regional governance in the context of rural development policy (Böcher, 2008). Therefore, the power relationship between the agents involved is essential. The experience of LEADER in different countries shows different situations in the distribution of influence and power, for example Kovách (Kovách, 2000), referring to studies on the situation of LEADER in the last decade of the 20th century, notes the social, economic and political effects of the program's restructuring: In Spain, administrative bodies have been activated, in France local and departmental political leaders have taken the lead in LEADER activities, in some cases in Italy consortia of tour operators and state agencies have monopolized the LAGs (Kovách, 2000).

Describing the Spanish experience, Estivill writes that the number and quality of the actors involved in the partnership and the balance between their capacities are important, because partnerships can be like a theatre where only the main actors have roles and the rest are just audiences (Estivill, 2001), but they can also establish rules of the game that utilize the various talents of all involved (ibid.). Rural and local development is a market where agents compete for development resources and this market has traditionally been governed by general market tools of the EU and national states; however, being aware of errors and failures, without affecting the rules of market sharing, the EU has introduced ways of expanding and defining networks of agents involved (Kovách, 2000). The redistribution of power in this respect means that LEADER favours local rural social agents over national bureaucratic institutions (ibid.); nation states tend to pay attention to conditions that encourage more active involvement of local agents when reviewing the terms of reference of LAGs. However, there are studies that prove the success of LEADER and the role of the LAGs, for example in strengthening social capital, diversifying the rural economy, improving the physical environment (Pylkkänen, Hyyruläinen, 2004; Grandberg et al., 2015). Finland's experience shows that the success of LEADER has been greatly influenced by the networking-based national rural development policy and the viability and functional capacity of civil society in the countryside (Pylkkänen, Hyyruläinen, 2004). It is precisely because of the well-functioning civil society in the countryside, the high level of social capital and the level of trust between individuals that the LAGs were quickly brought to life by the local communities (ibid.). Moseley, Cherrett and Cawley focus on the positive experience of Irish partnerships, pointing out that through partnerships, community and voluntary sector organizations have been empowering and becoming more active in the planning and delivery of local development programs (Moseley et al., 2001). Another benefit is the learning process, in which both social agents and individuals become more skilled and knowledgeable about local development (Moseley et al., 2001). Referring to research in Ireland and other European countries, Moseley and his co-authors point out that a collaborative atmosphere, the presence of key people, the presence of valuable resources, local knowledge or know-how, traditions and identity have been key to successful partnerships, whereas, in the surveys, the main difficulties identified by local people were lack of motivation for involvement (internal factor), lack of funding, lack of coordinated action and bureaucracy (external factors) (Moseley et al., 2001). It is concluded that cooperation is often the result of partnerships, not the other way around; the partnership approach was based on the desire to address problems in a coordinated way, to involve the local community and to raise funding. Similar observations exist in the operation of partnerships from other countries (e.g. Grandberg et al., 2015). Community involvement in sustainable local development needs to be analysed in terms of its knowledge, skills and learning processes (e.g. Tovey, 2008; Dargan, Shucksmith, 2008, Scott, 2004; Moseley, 2003; Moseley, 2003; Kilpatrick, Falk, 1999; Kilpatrick et al., 1998), as well as the knowledge and experience-based impact and power positions in particular initiatives and projects (Csurgó et al., 2008). Research acknowledges that rural development projects use different types and levels of knowledge that influence the capacity of these agents, such as scientific knowledge, political knowledge and management skills, local know-how (Csurgó et al., 2008), which are often tacit knowledge that is difficult to formulate in words. The authors acknowledge that local knowledge can only be effectively used in collaboration with experts' formal knowledge (Csurgó et al., 2008).

Kilpatrick and Falk conclude that there are two types of social capital at community level (Kilpatrick, Falk, 1999). The first is the interaction infrastructure, which provides a network that in turn helps individuals identify whom from the community to interact with and what procedures of interaction are. The second is the infrastructure of values and attitudes that underlie interactions. It describes the level of trust, values, and attitudes that determine how easily a community interacts (Kilpatrick, Falk, 1999). Adaptation and change are learning processes for individuals, groups, organizations and communities to create new knowledge, skills and values (Kilpatrick et al., 1998). Kilpatrick and Falk believe that if communities are to adapt and change, external interaction links are essential because the community then has access to knowledge and identity resources from the wider society, more social capital and potentially better outcomes (Kilpatrick, Falk,1999). This is related with developing of bridging and bonding ties. When communities work together, they learn from each other, and bridging social capital is strengthened. By transferring this idea to partnership activities and rural development, collective or social learning in community (partnership) and knowledge 
management are essential to the success of partnerships and virtually any aspect of rural development. Collective 'learning by doing' and engaging in a specific initiative (practice) makes partnerships into communities of practice. Moseley concludes that partnerships enhance community capacity by offering opportunities for many agents to be involved in planning, decision-making and project implementation, which can lead to both individual and institutional learning (Moseley (ed.), 2003, pp. 114). As the planning process progresses, local knowledge provides a more realistic identification of weaknesses and potential (spatial development capacity) of the local area. However, the capacities of agents influence both their involvement and their exclusion from community-level projects, and according to Csurgó with co-authors, projects become a new social "arena" creating a new social structure and hierarchy either social agents are involved in it or not (Csurgó et al., 2008, p. 301). Engagement is determined by the agents' embeddedness in the local community or network of project participants. Agents already engaged need to be able to adapt to certain behaviours, but those who do not have this capacity are displaced and lose access to project resources (ibid.)

Social agents, such as representatives of government bodies and funders, benefit from local knowledge because learning from the local experience helps to broaden and adapt their generalized knowledge to the local (Moseley, 2003). Reagans and McEvily point out that one of the most important ways people learn new things is to associate them with what they already know (Reagans \& McEvily, 2003). It follows that it is easier for people to learn something new in areas where they have prior knowledge and experience, and vice versa - it is easier to transfer knowledge to individuals who already have some common knowledge (similar or the same formal education and past experience in a particular field). Individuals with similar status in an informal communication network can also be said to have this common knowledge. Kelemen, Megyesi and Kalamász in their study on knowledge dynamics and sustainability in livelihood strategies in rural Hungary, citing various sources, point out that sustainability planning needs to involve a wide range of social agents with different knowledge, interests and value relationships; knowledge sharing in the community leads to learning (Kelemen et al., 2008). This learning is described as the result of reflexive communicative interaction between sustainability planning actors. The purpose of interaction is to collectively define the main directions of development, and this interaction depends on two conditions: interdisciplinary orientation, to promote the development of problem-solving, and methodological pluralism, which avoids the advantages of a particular form of knowledge (ibid.). At the same time, the authors of the study recognize that in reality, such a situation is rarely achieved in rural sustainability planning.

Alongside the partnership experience in Europe, a rural movement has developed which has acquired similar forms in various countries and is acting as non-governmental organizations. The initiative was founded in the Scandinavian countries, where village action movements have existed since the 1970s and 1980s. Halhead points out that rural social movements in Norway began 200 years ago (Halhead, 2005). Elsewhere in Europe, rural movements have started as a top-down initiative in a result of the forum of national organizations, whereas in the Scandinavian countries and Estonia the process has been reversed and movements have started as bottom-up initiatives; local communities mobilized themselves and became a national forum only at a later stage in the development of the movement (Halhead, 2005). The essence of rural movements is to mobilize local communities to become aware of their future, work together to help each other and influence policies at local, regional, national and EU level (Halhead, 2005). Halheda points out that rural movements have contributed to empowering communities by creating formal structures that help small and dispersed rural communities become aware of development opportunities in an integrated and effective way. Movements offer exchange of experience and training to enable social agents to be effective development planners and implementers. Movements offer exchange of experience and training to enable social agents to be effective development planners and implementers. This is how civil society (system) operates, which responds to the needs of rural areas, which the state could not solve. Rural parliaments movement in several European countries has developed as a new form of participatory democracy to strengthen civil society in rural areas. It aims to increase capacity of communities and create successful solutions and new opportunities for rural development by initiating multi-party cooperation at local, regional and national levels. In some EU countries (Sweden, Finland, the Netherlands, Estonia and Slovakia), rural parliaments emerged as an innovative alternative to gaining broader consensus on rural development policies at national level and to strengthen the civic voice for sustainable rural development (Šoster, 2011). Although such a movement has no direct influence on policy makers, democratic decision-making processes still have the opportunity to express their views and attitudes, reinforcing the bottom-up approach to decision-making. Four such parliaments of rural communities have already taken place in Latvia, including community parliamentary resolutions, which have been overseen by the Latvian Rural Forum.

\section{Conclusions and discussion}

All community development approaches have common traits and similarities in the guiding principles of their implementation, although the specific programs and objectives of different nation states or unions are specific. The author concludes that the involvement of communities in development processes is promoted through specific programs implemented by policy makers and initiatives by communities and non-governmental organizations. Communities use tailor-made support tools, build community organizations and networks to express their needs nationally, share experience and mobilize resources to implement their ideas. In addition, through historical development, the concept of community development has acquired various connotations. Understanding varies from communities as solely passive receivers of aid via specific schemes (mostly top-down approach) to communities as active agents of change enabling grass-roots initiatives (bottom-up approach) and building up local capacity. This is what also Kaufman's discussed (Kaufman, 1959) distinguishing development of community and development in community. 
The experience of different countries shows both top-down and bottom-up approaches and initiatives, each with its own weaknesses and strengths. Even though community-led local development in LEADER type partnerships has gained great success throughout Europe as fostering bottom-up initiatives, there is an evidence on uneven distribution of influence and power among local partners (Kovách, 2000) thus threatening basic principles of working in partnership.

This is because community involvement in development is influenced by many factors, such as democratic traditions and societal experience, the distribution of power and the exchange of knowledge between the social agents involved in development processes, the availability of resources and the skills to use them.

Community projects is another way in which local agents can participate in improving the quality of life and solving local problems. However, their realization depends on many factors, and there have been some concerns about the capacity of communities to implement projects. Such cases reaffirm the importance of trust, engagement with external community agents, and similar understanding of the situation in community development.

\section{REFERENCES}

1. Bently G., Pugalis L. 2014. Shifting Paradigms: People-centred Models, Active Regional Development, Space-blind Policies and Place-based Approaches. Local Economy, Vol. 29(4-5), pp. 283-294.

2. Bhattacharyya J. 2004. Theorizing Community Development. Journal of the Community Development Society, Vol. 34(2), pp. 5-34.

3. Bowen A.G. 2005. Local-Level Stakeholder Collaboration: A Substantive Theory of Community-Driven Development. Community Development, Vol. 36(2), pp. 73-88.

4. Böcher M. 2008. Regional Governance and Rural Development in Germany: The Implementation of LEADER+. Sociologia Ruralis, Vol. 48(4), pp. 372-388.

5. Cox K.R., Mair A. 1988. Locality and Community in the Politics of Local Economic Development. Annals of the Association of American Geographers, Vol. 78(2), pp. 307- 325.

6. Csurgó B., Kovách I., Kučerová E. 2008. Knowledge, Power and Sustainability in Contemporary Rural Europe. Sociologia Ruralis, Vol. 48(3), pp. 292-312

7. Dargan L., Shucksmith M. 2008. LEADER and Innovation. Sociologia Ruralis, Vol. 48(3), pp. $274-291$.

8. DeFillipps, J., Saegert, S. 2012. Communities Develop: The Question is, How? In J. DeFillipps, S., Saegert (Eds.). The Community Development Readers (2nd ed.) (pp. 1-7). New York: Routledge.

9. Eade D. 2007. Capacity Building: Who Builds Whose Capacity? Development in Practice, Vol. 17(4-5), pp. 630-639.

10. Estivill J. 2001. A New Approach to Partnership: The Spanish Case. In J. Benington, \& M. Geddes (Eds.). Local Partnerships and Social Exclusion in the European Union (pp. 152-169). London and New York: Routledge.

11. European Commission. 2014. Community-led Local Development. Available at http://ec.europa.eu/regional policy/sources/docgener/informat/2014/community en.pdf (accessed on 10/09/2019)

12. European Funding Network. 2012. Community Led Local Development - An Essential Element in the Delivery of the New European Structural Funds. Available at http://europeanfundingnetwork.eu/policy/cohesion-policy-20142020/CLLDCASESTUDIESEFNFinal.pdf (accessed on 10/09/2019)

13. Grandberg L., Andersson K., Kovách I. 2015. Evaluating the European Approach to Rural Development. Farnham, Burlington: Ashgate

14. Granovetter M. S. 1973. The Strength of Weak Ties. American Journal of Sociology, Vol. 78, pp. 1360-1380.

15. Halhead V. 2005. The Rural Movements of Europe. Brussels, Belgium: PREPARE - Partnership for Rural Europe. Available at http://www.preparenetwork.org/files/differ/rural_movments_of_europe_part_1.pdf (accessed on 10/09/2019)

16. Kaufman H. F. 1959. Toward an Interactional Conception of Community. Social Forces, Vol. 38, pp. 8-17.

17. Kelemen E., Megyesi B., Kalamász N.I. 2008. Knowledge Dynamics and Sustainability in Rural Livelihood Strategies: Two Case Studies from Hungary. Sociologia Ruralis Vol. 48(3), pp. 257-273.

18. Kilpatrick S., Falk I., Harrison L. 1998. Learning in Rural Communities: A Response to Rapid Economic Change (Discussion Paper D13/1998, CRLRA Discussion Paper Series). University of Tasmania. Available at http://www.researchgate.net/profile/Sue_Kilpatrick/publication/251796041_LEARNING_IN_RURAL_COMMUNITIES_A_R ESPONSE_TO_RAPID_ECONOMIC_CHANGE/links/0c96052d36beeba122000000.pdf (accessed on 10/09/2019)

19. Kilpatrick S., Falk I. 1999. Benefits for All: How Learning for Farming Can Build Social Capital in Communities (Discussion Paper D6/1999, CRLRA Discussion Paper Series). University of Tasmania. Available at http://www.researchgate.net/profile/Sue Kilpatrick/publication/242181511 BENEFITS FOR ALL HOW LEARNING FOR FARMING_CAN_BUILD_SOCIAL_CAPITAL_IN_COMMUNITIES/links/0c96052d36bef1f868000000.pdf (accessed on 10/09/2019)

20. Kovách I. 2000. LEADER, a New Social Order, and the Central- and East-European Countries. Sociologia Ruralis, Vol. 40(2), pp. 181-189.

21. Krawchenko T. 2014. Bringing Municipalities into Rural Community and Economic Development: Cases from Atlantic Canada. The Journal of Rural and Community Development, Vol. 9(3), pp. 78-96.

22. Kretzmann J. P., McKnight J. L. 1993. Building Communities from the Inside Out: A Path Toward Finding and Mobilizing a Community's Assets. Chicago: ACTA

23. Kumpulainen K., Soini K. 2019. How Do Community Development Activities Affect the Construction of Rural Places? A Case Study from Finland. Sociologia Ruralis, Vol. 59(2), pp. 294-313. 
24. The Aspen Institute Rural Economic Policy Program. Measuring Community Capacity Building. Available at http://www.aspeninstitute.org/publications/measuring-communitycapacity-building (accessed on 10/09/2019)

25. Lowe P., Phillipson J., Proctor A., Gkartzios M. 2019. Expertise in Rural Development: A Conceptual and Empirical Analysis. World Development, Vol. 116, pp. 28-37.

26. McAreavey R. 2008. Researcher and Employee: Reflections on Reflective Practice in Rural Development Research. Sociologia Ruralis, Vol. 48(4), pp. 389-407.

27. MacLeod M.A., Emejulu A. 2014. Neoliberalism with a Community Face? A Critical Analysis of Asset-Based Community Development in Scotland. Journal of Community Practice, Vol. 22(4), pp. 430-450.

28. Mansuri G., Rao V. 2004. Community-Based and -Driven Development: A Critical Review. The World Bank Research Observer, Vol. 19(1), pp. 1-39.

29. Mathie A., Cunningham G. 2003. From Clients to Citizens: Asset-Based Community Development as a Strategy for Community-Driven Development. Development in Practice, Vol. 13(5), pp. 474-486.

30. Moseley J.M., Cherrett T., Cawley M. 2001. Local Partnerships for Rural Development: Ireland's Experience in Context. Irish Geography, Vol. 34(2), pp.176-193.

31. Moseley J.M. 2003. Rural Development: Principles and Practice. London, Thousand Oaks, New Delhi: SAGE.

32. Moseley J.M. (Ed.) 2003. Local Partnerships for Rural Development: the European Experience. Wallingford: CABI Publishing.

33. Noya A., Clarence E., Craig, G. (Eds.) 2009. Community Capacity Building: Creating a Better Future Together. Paris: OECD.

34. O'Hara P. 1998. Action on the Ground: Models of Practice in Rural Development. Galway: Irish Rural Link.

35. Peters R. (Ed.) 2012. LEADER and Cooperation. EU Rural Review: A Publication from the European Network for Rural Development. No.11.

36. Pylkkänen P., Hyyruläinen T. 2004. Mainstreaming of the LEADER Method into Rural Development Policies in Finland. Maaseudunuusi aika, Vol. 4(12), English Supplement, pp. 22-32.

37. Reagans R., McEvily B. 2003. Network Structure and Knowledge Transfer: The Effects of Cohesion and Range. Administrative Science Quarterly, Vol. 48, pp. 240-267.

38. Scott M. 2004. Building Institutional Capacity in Rural Northern Ireland: The Role of Partnership Governance in the LEADER II Programme. Journal of Rural Studies, Vol. 20(1), pp. 49-59.

39. Snyder H. 2019. Literature review as a research methodology: An overview and guidelines. Journal of Business Research, Vol. 104, pp. 333-339.

40. Summers G.F. 1986. Rural Community Development. Annual Review of Sociology, Vol. 12, pp. 347-371.

41. Šoster, G. 2011. Perspectives of Civil Society in European Rural Development. In G. Šoster, \& V. Halhead (Eds.). Rural Parliaments: Emerging Participative Democracy (pp. 9-21). Brussels, Ljutomer: PREPARE Network.

42. Titscher S., Meyer M., Wodak R., Vetter E. 2000. Methods of text and discourse analysis. London, Thousand Oaks, New Delhi: SAGE Publications.

43. Tovey H. 2008. Introduction: Rural Sustainable Development in the Knowledge Era. Sociologia Ruralis, Vol. 48(3), pp. 185199.

44. Turvey R. 2006. Development from within: An Evaluative Research on Economic Development Strategies. GeoJournal, Vol. 67, pp. 207-222.

45. Ward, V., House, A., \& Hamer, S. (2009). Developing a framework for transferring knowledge into action: A thematic analysis of the literature. Journal of Health Services Research and Policy, Vol. 14, 156-164. Available at https://doi.org/10.1258/ihsrp.2009.008120 (accessed on 60/01/2020). 